\title{
CCND2 Protein Overexpression
}

National Cancer Institute

\section{Source}

National Cancer Institute. CCND2 Protein Overexpression. NCI Thesaurus. Code C141364.

A molecular abnormality indicating the presence of an abnormally high level of the G1/Sspecific cyclin-D2 protein. 